\title{
GULA E LITERATURA: DIÁLOGO GASTRONÔMICO COM A OBRA DE EÇA DE QUEIRÓS
}

José Roberto de Andrade ${ }^{1}$

Recebido: 07/03/2015

Aprovado: $16 / 12 / 2015$

\section{RESUMO}

O escritor Eça de Queirós (1845-1900) não se destacou pelas habilidades culinárias, mas marcou a cozinha portuguesa. Sua obra literária e jornalística revela que Eça escolheu representar, também pela perspectiva do estômago, a sociedade portuguesa de sua época, aproximando o escritor do cozinheiro. Neste artigo, comentam-se textos jornalísticos do escritor português e faz-se a leitura de um jantar de O Primo Basílio para destacar a possibilidade de diálogos entre a obra do escritor e a gastronomia e a importância deste tema como chave interpretativa dos textos ecianos.

Palavras-chave: Eça de Queirós; Literatura Portuguesa; Gastronomia; O Primo Basílio.

\section{GLUTTONY AND LITERATURE: GASTRONOMIC DIALOGUE WITH EÇA DE QUEIRÓS’ WORK}

\begin{abstract}
Portuguese writer Eça de Queirós (1845-1900) has not only been noticed due to its culinary skills but has also influenced Portuguese cuisine itself. His literary and journalistic work reveals that Eça chose to portrait the Portuguese society of his time from a stomach point of view, intertwining the writer's and the cook's makings. To highlight the relevant role gastronomy plays as an interpretive key of Eça's texts, we will comment in this paper about some of the writer's journalistic texts as well as read one of the diners depicted in O Primo Basilio.
\end{abstract}

Keywords: Eça de Queirós; Portuguese Literature; Gastronomy; O Primo Basílio.

O escritor português Eça de Queirós (1845-1900) não se destacou pelas habilidades culinárias, mas marcou, literariamente, a cozinha portuguesa. Talvez seja possível ler sua obra como uma experimentação de "receitas" e "ingredientes". Ele teria, por exemplo, "cozinhado" e "servido" padres e carolas, n'O crime do padre Amaro, a família burguesa, n'O primo Basilio, bacharéis, $\mathrm{n}^{\prime} A$ Relíquia e n'O Mandarim, e a burguesia e nobreza decadente, $\mathrm{n}^{\prime} O$ s Maias, n'A Ilustre Casa de Ramires e n'As cidades e as serras.

Neste artigo, procurarei, de forma sucinta, dar destaque a alguns textos jornalísticos em que Eça de Queirós tratou de cozinha e a alguns estudos que ressaltam a importância da gastronomia nas narrativas ecianas. Também analisarei uma das cenas do romance O Primo Basilio, publicado em 1880, para exemplificar como o “cozinheiro” Eça de Queirós elabora gastronomicamente personagens e enredo. Comecemos pelos textos jornalísticos.

\footnotetext{
${ }^{1}$ Doutor em Literatura pela UFBA, professor do IFBA, campus Salvador.

E-mail: andrade.escolas@gmail.com
} 
Comida e comer foram temas em vários dos textos jornalísticos do escritor. Num dos artigos publicados na Gaz̧eta de Portugal, em 1867, Eça compara Lisboa a outras cidades históricas. Em tudo encontra semelhanças: Lisboa tem a mesma quantidade de colinas que Roma: sete; o céu de Lisboa é tão transparente quanto o de Atenas; e tal qual Jerusalém, sacrifica os que querem lhe dar alma. Diferentemente de outras cidades, no entanto, "Lisboa o que faz? Come!". E só se pode ver seu brilho e sua beleza, à noite, depois que a cidade comeu. (III, p. 79) ${ }^{2}$. As cidades comem, mas os santos devem jejuar: em artigo intitulado "Encíclica Poética", publicado na Revista Moderna em 1897, com fina ironia, Eça de Queirós ataca as orientações do papa Leão XIII sobre a alimentação cristã afirmando que, se seguissem as orientações do sumo pontífice, os cristãos, além de engordar, nunca seriam santos. A mastigação das cidades e dos cristãos não foram as únicas incursões de Eça pela cozinha. O texto mais exemplar e programático sobre o tema talvez seja o artigo conhecido como "Cozinha Arqueológica”, publicado em 1893, na Gazeta de Notícias. Nele, Eça afirmou: "a mesa constituiu sempre um dos fortes, se não o mais forte alicerce das sociedades humanas" e "O caráter de uma raça pode ser deduzido simplesmente de seu método de assar a carne" (III, p. 1226). A declaração ressalta a intrínseca relação entre comida e sociedade, que Eça reforça, ao adicionar: "a cozinha e adega exercem uma tão larga e direta influência sobre o homem e a sociedade", por isso "dize-me o que comes, dir-te-ei o que és" (III, p. 1226). Penso que Eça não se incomodaria se acrescentasse "com quem" e "como" a este último período: "diga-me o que comes [como comes e com quem comes] e dir-te-ei quem és". O acréscimo é apropriado, pois Eça destaca a necessidade de se fazer a "arqueologia" daí o título do artigo - do sistema culinário greco-romano, ou seja, dizer o que, com quem e como a sociedade comia para entender as relações entre cozinha, processos de cozimento e relações sócio-políticas.

Ao tratar de culinária em seus artigos jornalísticos, Eça ecoa ideias de tratados gastronômicos de época, como Fisiologia do Gosto, publicado em 1825, pelo célebre advogado, político e cozinheiro francês Brillart Savarin, e - como todo autor excepcional - antecipa reflexões de historiadores como Jean François-Revel (1996) e Massimo Montanari (2004), para quem os valores do sistema alimentar são resultado da representação dos processos

\footnotetext{
2 Os trechos da obra de Eça de Queirós foram retirados da edição, em quatro volumes, publicada pela editora Aguilar, sob a coordenação de Beatriz Berrini. Nas citações, referir-me-ei simplesmente aos volumes (I, II, III e IV) e às páginas.
} 
culturais e a relação humana com os alimentos se estabelece segundo critérios econômicos, nutricionais e simbólicos. Por isso a comida "se configura como um elemento decisivo de la identidad humana y como uno de los instrumentos más eficaces para comunicarla" (MONTANARI, 2004, p. 10). Além de ecoar e antecipar, as afirmações de Eça, tomadas na perspectiva da proposta de representação realista da sociedade portuguesa, significam, em alguma medida, considerar a cozinha e a comida como forma de caracterizar personagens e sociedade. Comida seria também matéria a ser observada e moldada nas narrativas. No caso de Eça de Queirós, essa interpretação torna-se mais consistente à medida que se saboreia, na obra, a "arqueologia culinária" da sociedade portuguesa. O escritor não só propôs a observação da cozinha nas sociedades clássicas, mas também considerou, em certa medida, a gastronomia como arqué - elemento básico - das representações da sociedade portuguesa. Arqué que foi notada por vários de seus leitores e críticos.

A comida despertou a atenção Machado de Assis, já em 1878. Na conhecida crítica sobre O Primo Basilio, Assis arrolou "a pilha de doces", da confeitaria em que se encontram casualmente Sebastião e Juliana, e "o longo jantar do Conselheiro Acácio" entre os itens que configurariam a exagerada preocupação de Eça pelo acessório. A importância da leitura de Machado de Assis, naquele momento, não reside somente no fato de ter vislumbrado a mesa como elemento da narrativa, mas também na maneira como elabora seu raciocínio. A excessiva ênfase no acessório seria decorrente das preocupações com os princípios da escola realista: "O sr. Eça de Queirós não quer ser um realista mitigado, mas intenso e completo" (ASSIS, 1997, p. 908). O que Assis não conseguiu intuir é que, para ser zeloso com os princípios da escola, Eça poderia ter esquecido a cozinha e dado atenção somente ao guardaroupa ou à biblioteca. Mas foi zeloso com a comida também. Machado de Assis viu aí fartura desnecessária. Ao argumento do excesso, no entanto, pode-se contrapor o da coerência gastronômica que se constitui ao longo da obra. A comida seria um excesso de escola, se Eça não tivesse continuado a ser zeloso com o tema. O cuidado com a comida só fez aumentar de quantidade e qualidade nas obras e versões posteriores, reforçando a hipótese de que o autor de Os Maias pode ter escolhido a cozinha como elemento fundamental de seu projeto de representação de Portugal.

Mais recentemente, a importância da comida nesse projeto de representação foi notada por vários estudiosos da sua obra. Destacarei alguns. 
A variedade da cozinha eciana inspirou obras como Era Tormes e amanhecia: dicionário gastronômico cultural de Eça de Queirós. O autor, Dario Moreira de Castro Alves, organizou e catalogou 400 verbetes culinários, com 4.488 citações das obras de Eça. Na apresentação de seu dicionário, Castro Alves ressalta que "Por toda a obra do grande escritor o tema comer surge de forma poderosa, sob os mais variados ângulos: o comer bem, o comer muito, o jantar na hora vernácula, o comer mal, a tolerância e simpatia com a glutonaria...” (ALVES, 1992, p. 15).

$\mathrm{Na}$ busca por interpretar a variedade catalogada por Castro Alves, encontram-se autores como José dos Santos Werneck, que, em estudo publicado em 1946, escreveu:

Em toda obra variada de Eça - romance, conto, crônica, lendas de santos e até na correspondência particular, há um constante movimento de talheres, retinir de baixelas, ou sons abafados de grosseiras malgas, que contribuem poderosamente para a compreensão do ambiente, material e moral e a caracterização das personagens (WERNECK, 1946, p. 161).

Percepção semelhante à de Werneck tem a professora Andrée Crabé Rocha, responsável pelo verbete "Alusões Alimentares”, do Dicionário de Eça de Queirós, organizado por A. Campos Matos (1988). A quantidade e a extensão das cenas gastronômicas e a intensa utilização da culinária para caracterizar seus personagens revelam obsessão pelo tema e despertam a seguinte dúvida: a gastronomia não teria conduzido Eça de Queirós a exorbitar "nesta via, deixando-nos uma visão distorcida dos homens de seu tempo"? (ROCHA apud MATOS, 1988, p. 63).

Sem se questionar sobre as possíveis distorções na realidade representada, a pesquisadora Maria José de Queiróz destacou a importância do tema na obra de Eça de Queirós. Mineira e gourmet, escreveu o excelente $A$ Literatura e o Gozo Impuro da comida. Nas onze páginas dedicadas a Eça - a maior quantidade para um único escritor -, identifica os endereços gastronômicos frequentados pelo autor e por suas personagens - O restaurante do Hotel Central, em que João da Ega oferece o jantar ao Cohen, em Os Maias, teria sido o mesmo em que Eça pediu a mão de sua esposa, Emília -, refere-se à disposição do autor para oferecer boa comida aos amigos e a seus problemas gástricos, que o impediam, muitas vezes, de saborear as iguarias de que gostava. A autora, no entanto, não se restringe à identificação do espaço do mundo, representante, e o espaço da ficção, representado, e às relações entre autor e gastronomia. Ela quer demonstrar que o tema teve papel importante na literatura de língua portuguesa. E Eça é um dos seus autores exemplares. Nele, a culinária 
não é mero tema decorativo. Instruído na fisiologia do gosto, leitor de Flaubert e Zola, dispensa-lhe o desvelo de um aficionado um aficionado à nona arte e a atenção de um discípulo do realismo (QUEIRÓZ, 1994, p. 202).

A atenção seria decorrente, também, da "grande vocação de gourmet" e do empenho pessoal "na condenação da sociedade" que levariam o escritor a projetar, em suas personagens, as delicadezas do paladar exigente e "[a] pinta[r] com crueza os excessos do ventre":

Servem-se também à mesa a falta de pudor, de modéstia com que os burgueses agridem a moral e os costumes. Fortemente acentuado pelos traços da caricatura, o apetite instrui as mais variadas formas de comportamento. Compete à temperança e à gula determinar as reações instintivas, as peculiaridades de caráter e demais pronunciamentos da individualidade (QUEIRÓZ, 1994, p. 202-203).

Os comportamentos gastronômicos das personagens e a importância da culinária na obra eciana também não escaparam à observação atenta de Beatriz Berrini, que preparou a edição da Obra Completa de Eça de Queirós e organizou o belíssimo Comer e beber com Eça de Queirós (1995), livro que traz receitas inspiradas nas narrativas ecianas e instrui os leitores a elaborar os pratos, alguns oferecidos na Fundação Eça de Queirós, em Tormes, onde o percurso turístico passa pela "mesa de Eça". Berrini afirma que as personagens ecianas comem, bebem e sentem prazer ou desprazer com isso. Comer e beber são elementos da representação crítica dos costumes sociais da época e as considerações em torno das refeições contribuem, por exemplo, para desenvolvimento do enredo, apresentação e caracterização das personagens, exposição de ideias e marcação de contrastes.

Castro Alves, Werneck, Rocha, Queiroz e Berrini referem-se ao conjunto da obra eciana e indicam que o zelo com a comida não era, como imaginou Machado de Assis, um exagero de escola. Em Eça de Queirós, as cenas gastronômicas estruturam o ambiente moral e material, servem à caracterização das personagens, ao desenvolvimento do enredo e ao exercício da crítica e da sátira. Assim, a cozinha, em certa medida, ordena o universo narrativo de Eça e revela uma importante possibilidade de interpretação de seu projeto de representação da sociedade portuguesa. Em artigos anteriores (ANDRADE, 2012 e 2013) procurei destacar como esse projeto se concretiza em O Crime do Padre Amaro, Os Maias, A Relíquia e O Mandarim. Aqui, analisarei uma cena de O Primo Basilio, com o objetivo de 
exemplificar os procedimentos de Eça de Queirós na caracterização gastronômica de seus personagens.

Como sugeri anteriormente, o ingrediente principal d'O Primo Basílio é a família da burguesia média de Lisboa. O romance inicia-se Jorge e Luísa vivendo o idílio, a placidez e a estabilidade de um casamento burguês. As exigências do trabalho de Jorge, um engenheiro de minas, levam-no a viajar pelo Alentejo e deixar Luísa, solitária e entediada, em Lisboa. Nesse momento, volta do Brasil o primo Basílio, com quem Luísa conviveu e flertou na adolescência. Ele se reaproxima da prima, inicia um jogo de sedução e é correspondido. A criada de Luísa, Juliana, apodera-se de uma carta de amor que Luísa escreve a Basílio e chantageia a patroa. No final, a carta é recuperada e Juliana morre, mas Jorge descobre a traição e o final é trágico também para Luísa.

Se em outras obras a culinária contribui para o desenvolvimento do enredo e caracterização das personagens, n'O Primo Basílio não poderia ser diferente. Analisarei a cena de um jantar que Luísa oferece a sua amiga Leopoldina para entender qual o papel da mesa e da comida nessa caracterização. Na edição das obras completas, a cena, desde a chegada de Leopoldina até sua saída da casa de Luísa, vai da página 561 à 569, do capítulo X, volume I, mas há dois importantes episódios anteriores: ausência de Basílio e a visita de Sebastião. Naquele dia, Basílio não veio visitar Luísa, que está, por isso, preocupada e entristecida. Ela começa a escrever uma carta para o primo, mas é interrompida pela chegada de Sebastião, amigo do casal, que vem para alertar Luísa sobre os comentários da vizinhança: as "línguas danadas" (I, p. 559) já falam das visitas diárias de Basílio. Luísa ouve as admoestações do amigo, mas sente-se contrariada, irritada e injustiçada. A intromissão de Sebastião e "os 'palratórios' da rua” são pérfidos e inaceitáveis, principalmente se contrastados com a imagem que Luísa faz de si: ela tinha certeza de que "podia ter lá dentro uma fraqueza... Mas seria sempre uma mulher de bem, fiel, só dum!” (I, p. 561).

Ao receber a amiga Leopoldina, Luísa está, portanto, triste e preocupada com a ausência do primo, exasperada com a invasão de sua intimidade, irritada com os comentários da vizinhança e já envolvida no jogo de sedução que Basílio iniciou. Nutre desejo pela aventura adúltera e o jantar com a amiga vai apimentar essa vontade. Embora tenham sido vizinhas e amigas íntimas no colégio, Leopoldina é conhecida por suas aventuras amorosas, por suas ideias "sediciosas" e não é — principalmente segundo os maridos — companhia 
adequada para "uma mulher de bem, fiel, só dum!" ${ }^{3}$ Luísa, entretanto, percebe-se forte e capaz de resistir à "má influência" de Leopoldina e a recebe para jantar. A fragilidade de Luísa e a ascendência de Leopoldina sobre ela vão, porém, se concretizar antes, durante e depois do jantar. Antes de sentarem à mesa, Leopoldina:

- detalha as exigências e desmazelos de Justina, sua criada;

- fala da ausência do marido: "Lá o meu senhor foi para o Campo Grande" (I, p. 562);

- menciona seus amantes, sem deixar de se demonstrar independência crítica e "paladar": esteve para jantar com um deles, mas “olha, a falar a verdade, nem sabia onde, nem tinha dinheiro... Que ele coitado com a sua mesada mal the chega. Disse comigo: nada, vou ver a Luísa” (I, p. 562).

Os temas do jantar e, também, da trama estão, portanto, postos à mesa, antes do caldo e do assado: criadas, amantes e maridos. E o tratamento desses temas já revelam os contrastes básicos das personagens. Luísa entristece com a ausência de Basílio e pretende ser mulher de um homem só, anunciando, em certa medida, sujeição e dependência. Leopoldina, diferentemente, queixa-se das criadas, mas demonstra maleabilidade para não as contrariar "quando a gente depende delas" (I, p. 562); reclama do marido, mas não deixa de chamá-lo "meu Senhor"; entrega-se às aventuras amorosas, mas posiciona-se com independência em relação aos amantes: dispensa o atual por não ter mesada que permita oferecer certeza de qualidade no "cardápio" e no "restaurante". Essa relativa autonomia e flexibilidade vão se acentuar em Leopoldina, a começar pelo relativo desrespeito à "etiqueta gastronômica", interferindo no cardápio:

- Tens tu bacalhau?

Devia haver, talvez. Que extravagância! Por quê?

- Ai! — exclamou. - Manda-me assar um bocadinho de bacalhau! Meu marido detesta bacalhau! Aquele animal! Eu é a minha paixão. Com azeite e alho! - Mas calou-se, contrariada — Diabo!

- O quê?

—É que hoje não posso comer alho... (I, p. 562)

\footnotetext{
${ }^{3}$ Talvez seja importante retomar um trecho da caracterização de Leopoldina:

Era a sua íntima amiga. Tinham sido vizinhas, em solteiras, na Rua da Madalena, e estudado no mesmo colégio, à Patriarcal, na Rita Pessoa, a coxa. [...] Tinha feito um casamento infeliz com um João Noronha, empregado da Alfândega. [...]

Sabia-se que tinha amantes, dizia-se que tinha vícios. Jorge odiava-a. E dissera muitas vezes a Luísa: Tudo, menos a Leopoldina!

Leopoldina tinha então vinte e sete anos. Não era alta, mas passava por ser a mulher mais bem feita de Lisboa. (I, p. 464)
} 
Leopoldina aproveita a ausência do marido, que não suporta a iguaria, e exige o extravagante bacalhau, mas se priva, inicialmente, do alho, para resguardar a "etiqueta amorosa". Privação momentânea. Entre o amor e o sabor, Leopoldina escolhe os dois: come a seu gosto e, com hálito de alho, vai ao encontro de Fernando, poeta e amante:

E como Juliana entrava com o bacalhau assado, fez-lhe uma ovação!

- Bravo! Está soberbo!

Tocou-lhe com a ponta do dedo, gulosa; vinha louro, um pouco toscado, abrindo em lascas.

— Tu verás — dizia ela. — Não te tentas? Fazes mal!

Teve então um movimento decidido de bravura, disse:

— Traga-me um alho, Sra. Juliana! Traga-me um bom alho!

E apenas ela saiu:

— Eu vou ter logo com o Fernando, mas não me importa!... Ah! Obrigada, Sra. Juliana! Não há nada como o alho!...

Esborrachou-o em roda do prato, regou as lascas do bacalhau de um fio mole de azeite, com gravidade. - Divino! - exclamou. Tornou a encher o copo; achava aquilo uma pândega. (I, p. 564-565).

Ao solicitar o bacalhau e, depois, o alho, Leopoldina caracteriza-se como decidida, corajosa, gulosa e amante da diversão e do prazer. Essas características contrastam com as de Luísa - que se espanta com a extravagância da amiga e, aparentemente, não se deixa "tentar" pelo bacalhau - e vão somar-se a outras como, por exemplo: desafinada e teatral interprete de fado. Enquanto espera o bacalhau assar, canta para atender ao desejo de Luísa: “queria alguma coisa triste, doce... O fado! Que tocasse o fado!” (I, p. 563). O desejo de Luísa relaciona-se ao seu estado de tristeza e de dupla solidão, já que o marido está distante e o primo não veio para a visita diária. Leopoldina escolhe cantar o mais recente e sentimental fado que circula nos salões de Lisboa:

— Ai, o fado novo! Tu não ouviste? É lindo! Os versos são divinos! $[\ldots]$

- Tu não sabes isto, Luísa? Oh, filha! É o último! É de chorar! Recomeçou, com o tom muito quebrado. Era a história rimada de um amor infeliz. Falava-se nas "raivas do ciúme, nas rochas de Cascais, nas noites de luar, nos suspiros da saudade", todo o palavreado mórbido do sentimentalismo lisboeta. Leopoldina dava tons dolentes à voz, revirava um olhar expirante; uma quadra sobretudo enternecia-a; repetiu-a com paixão:

Vejo-o nas nuvens do céu,

Nas ondas do mar sem fim,

E por mais longe que esteja

Sinto-o sempre ao pé de mim.

— Lindo! - suspirava Luísa. 
E Leopoldina terminava com ais! em que a sua voz se arrastava numa extensão desafinada. (I, p. 562-563).

Luísa mostra-se inapetente, melancólica e encanta-se com “o palavreado mórbido do sentimentalismo lisboeta". Leopoldina, diferentemente, é apaixonada e exageradamente fervorosa ao interpretar o fado, mas não se deixa tomar pela melancolia da música. À mesa, faz-se loquaz e "servia-se muito, com gula". Gulosa e apaixonada no servir, mas contida no comer: "depois picava um bocadinho na ponta do garfo, provava, deixava, punha-se a comer côdeas de pão que barrava de manteiga" (I, p. 563).

. A melancolia e a gula, em Leopoldina, são mais encenação que ação; ela não se entristece nem se empanturra. O que lhe permite rir e conversar animadamente com Luísa sobre alguns temas centrais do universo feminino.

Comendo o bacalhau, o assado, depenicando bagos de uvas e bebericando golinhos de vinho e de champanhe - que Leopoldina "se fosse rica, bebia sempre" (I, p. 566) —, Leopoldina fala de criadas, maridos, amantes e chega às recordações do colégio. As lembranças do colégio trazem para a mesa personagens e cenas da formação amorosa e sexual $^{4}$ de Luísa e Leopoldina. Lembram um tal Espinafre - a quem "todas [as meninas] escreviam bilhetes, desenhavam-lhe corações de onde saia uma fogueira" (I, p. 563) - e de Micaela que "foi apanhada, no cacifo dos baús, a devorá-lo [Espinafre] de beijos!...” (i, p. 563). Luísa reage à lembrança com uma exclamação de pudor — “que horror”! (I, p. 563) — mas não interrompe a conversa que, entre o assado, vinho, frutas, avança até os "sentimentos", eufemismo para se referir aos relacionamentos homoafetivos que ela e Leopoldina mantiveram com outras meninas. Novamente aqui, as amigas revelam diferentes concepções. Luísa classifica essas relações de “tolices” e Leopoldina entende que são amores intensos e duradouros:

Ai! Era sempre com saudades que falava dos sentimentos. Tinham sido as primeiras sensações, as mais intensas. Que agonia de ciúmes! Que delírio de reconciliações! E os beijos furtados! $\mathrm{E}$ os olhares! $\mathrm{E}$ os bilhetinhos, e todas as palpitações do coração, as primeiras da vida!

— Nunca — exclamou —, nunca, depois de mulher, senti por um homem o que senti pela Joaninha!... Pois podes crer... (I, p. 564).

\footnotetext{
${ }^{4}$ Afirmei em publicações anteriores que gula e luxúria estão estreitamente relacionadas na obra de Eça. Relação que foi percebida por Isabel Pires de Lima: “a aproximação entre gula e luxúria [...] é frequente no universo romanesco queirosiano" (1997, p. 717). Em Eça, os espaços dedicados à comida e à sexualidade (o comer no sentido metafórico) e os discursos sobre essas atividades estão intimamente relacionados. Neste artigo, não é nosso objetivo tratar dessa relação, mas é impossível não a perceber na cena escolhida para análise.
} 
Embora considere “tolices”, Luísa acompanha atentamente o discurso de Leopoldina e dele não discorda, apenas cuida para que a criada, Juliana, não ouça a conversa e se preserve a respeitabilidade da casa:

Um olhar de Luísa deteve-a. — A Juliana! Diabo! Tinha-se esquecido! [...]

— Ah! A respeitabilidade da casa! Tens razão! — murmurou. (I, p. 564) Mesma respeitabilidade que Luísa procura conservar quando Leopoldina deseja fumar:

[...] Sabes tu, fumava agora um cigarrito...

O pior é que Juliana podia sentir o cheiro. E parecia tão mal!...

— É um convento, isto! - murmurou Leopoldina. - Não tens má prisão, minha filha! (I, p. 566)

Fumo e relações homoafetivas não são recomendados a mulheres "de bem", mas são tolerados desde que se resguarde a aparência de moralidade. Essa dinâmica de respeito e de ataques aos bons costumes não se configura de forma simples. Leopoldina adota práticas que destoam das concepções morais da burguesia lisboeta, mas respeita, ainda que com uma ponta de ironia, os limites impostos a si - Gama, o marido, é senhor e proíbe o bacalhau na sua mesa - e à amiga: “não tens má prisão, minha filha”. E Luísa, embora tome o partido das aparências no caso do fumo e dos sentimentos, parece defender mais aguerridamente algumas das respeitáveis posições da família burguesa. Por exemplo, quando falam de religião e de Deus:

— Ah, os padres... - murmurou Luísa.

— Os padres quê? São a religião! Nunca vi outra. Deus, esse, minha rica, está longe, não se ocupa do que fazem as mulheres.

Luísa achava horrível aquele modo de pensar. A felicidade, a verdadeira, segundo ela, era ser honesta... (I, p. 566).

da promiscuidade de Leopoldina:

— Pois olha que com as tuas paixões, umas atrás das outras...

Leopoldina estacou:

- O quê?

— Não te podem fazer feliz!

— Está claro que não! — exclamou a outra. — Mas... — [...] disse apenas com um tom seco: - Divertem-me! (I, p. 568)

e da independência masculina, que Leopoldina inveja:

— Ah! — exclamou. — Os homens são bem mais felizes que nós! Eu nasci para homem! O que eu faria! 
$[\ldots]$

- Um homem pode fazer tudo! Nada lhe fica mal! Pode viajar, correr aventuras... (I, p. 566)

e Luísa desdenha: "São tolices, no fim, andar, viajar! A única coisa neste mundo é a gente estar na sua casa, com o seu homem, um filho ou dois...”. (I, p. 566)

A esposa de Jorge prega honestidade, defende que mulheres devam ficar em casa, criando os filhos — condição inaceitável para Leopoldina —, condena a promiscuidade amorosa e a maneira da amiga falar da religião e de Deus, mas não percebe os caminhos contraditórios que seu pensamento percorre durante o jantar. Embora fale da vida caseira e maternal, Luísa "ambicionava um cupê; e queria viajar, ir a Paris, a Sevilha, a Roma” (I. p. 566). A defesa da honestidade não tem espaço, quando o tema são os possíveis amantes de Luísa. Ela ruboriza na lembrança de Basílio:

E então Leopoldina, com os olhos no prato, partindo devagar, muito atenta, lascazinhas de bacalhau:

- E teu primo veio ver-te?

Luísa fez-se vermelha. (I, p. 565)

e sorri na menção a outro pretendente, o banqueiro Castro:

— Sabes quem me falou ontem de ti?

- Quem?

- O Castro.

$[\ldots]$

- Muito apaixonado por ti sempre.

Luísa riu. (I, p. 568-569)

O desejo de viagem, o rubor e o sorriso são indicativos da curiosidade e do desejo, que Luísa vai explicitar, quando Leopoldina, envolta num ar de confidência e sensualidade, continua a tratar de sua relação com seu atual amante, Fernando:

o champanhe, a meia obscuridade deram-lhe bem depressa a necessidade de cochichar confidenciazinhas. [...] pôs-se a falar dele. Era ainda o Fernando, o poeta. Adorava-o.

— Se tu soubesses! - murmurava com um ar de êxtase. — É um amor de rapaz!

A sua voz velada tinha inflexões de uma ternura cálida. Luísa sentia-lhe o hálito e o calor do corpo, quase deitada também, enervada; a sua respiração alta tinha por vezes um tom suspirado; e a certos detalhes mais picantes de Leopoldina soltava um risinho quente e curto, como de cócegas... (I, p. 569) 
A escuta atenta dos detalhes picantes, a aproximação física e o "risinho quente e curto" revelam mais interesse que indignação. E Leopoldina demonstra habilidade na condução da conversa: parte o bacalhau lentamente, observa as reações de Luísa, bebe o vinho e o champanhe, e espera estarem próximas, quase deitadas, para falar, "com ar de êxtase", do amante.

Em todos os diálogos e ações, Leopoldina se mostra — sem muitas vezes ser — gulosa, corajosa, questionadora, sedutora, apaixonada, pândega e amante dos prazeres da vida. Luísa se encanta com algumas características de Leopoldina e se deixa seduzir por elas, mas procura manter a imagem de esposa fiel, contida, respeitadora da religião e conservadora dos bons costumes familiares. É um jogo de aparências e conveniências que se constitui, também, no menu e na forma de comer. Quem recusa convites, direciona o cardápio e insiste no alho, apesar do amante, cria uma imagem de quem põe o prazer gustativo acima do amor, sem dispensar este último. E Leopoldina pauta a conversa, sugere o cardápio e serve-se com gula, mas só "belisca" o assado, as frutas, e trincha delicadamente e vagarosamente o bacalhau. Também saboreia o vinho e o champanhe, devagar, com gosto. Prefere comer antes de amar, mas não dispensa o amor, mesmo depois de comer alho. Leopoldina procura sentir prazer com a comida, com a conversa e com os amores que "divertem-me". Luísa aparece mais contida, não leva a comida à boca, entedia-se com a solidão, entristece-se por não realizar os desejos. Em certa medida, deixa de comer e de amar. Na mesa, Leopoldina demonstra, em relação à comida e à bebida, a mesma independência e distância relativa que consegue manter dos amantes e aos padrões sociais. Come e bebe do melhor, satisfaz o paladar, mas não se empanturra nem se embebeda. Luísa, diferentemente, quase não leva comida à boca, prefere ouvir e se embriagar com a melancolia do fado e o álcool do champanhe. E embora esboce críticas, revela-se seduzida pela personalidade forte e, em certa medida, masculina, de Leopoldina; sedução que vai continuar depois de servido o café.

Leopoldina parte para os braços do amante e Luísa fica só, em meio à "noite cálida, bela e doce, [que] atraía-a, chamava-a para fora, para passeios sentimentais, [...] com as mãos entrelaçadas" (I, p. 570). O calor da noite e o desejo do contato, trazem-lhe de volta "as conversas de Leopoldina e a lembrança das suas felicidades" (I, p. 570). Além disso, "uma pontinha de champanhe agitava-se no sangue" (I, p. 570). O calor, a solidão, a lembrança da conversa, a embriaguez, levam Luísa a: 
sem querer, não podia desprender a idéia de Leopoldina que ia ver o seu amante! O seu amante!... [...] — e que delicioso, que ávido, que profundo o primeiro beijo! Suspirou. Também ela amava - e um mais belo, mais fascinante. Por que não tinha vindo? (I, p. 570)

Nesse momento, em que pensa na aventura amorosa de Leopoldina, Luísa se esquece do marido, lembra do primo, e:

de repente a campainha retiniu. [...] Pôs-se a escutar assustada. Vozes falavam à cancela.

- Minha senhora - veio dizer Joana baixo — é o primo da senhora que se vem despedir...

Abafou um grito, balbuciou:

- Que entre!

Os seus olhos dilatados cravavam-se febrilmente na porta. [...] Basílio entrou, pálido, com um sorriso fixo.

— Tu partes! - exclamou ela surdamente, precipitando-se para ele.

— Não! - E prendeu-a nos braços. - Não! Imaginei que me não recebias a esta hora, e tomei este pretexto. (I, p. 570)

Toda a atmosfera do jantar atiçou o desejo em Luísa. Ela também está apreensiva com a ausência do primo. Por isso, o pretexto da partida é perfeito. Luísa estremece diante da possibilidade de perder o amante e não realizar seus desejos amorosos. Precipita-se para Basílio, que:

Apertou-a contra si, beijou-a; ela deixava, toda abandonada; os seus lábios prendiam-se aos dele. Basílio deitou um olhar rápido, em redor, pela sala, e foi-a levando abraçado, murmurando: - Meu amor! Minha filha! Mesmo tropeçou na pele de tigre, estendida ao pé do divã.

- Adoro-te!

— Que susto que tive! — suspirou Luísa.

- Tiveste?

Ela não respondeu; ia perdendo a percepção nítida das coisas; sentia-se como adormecer; balbuciou: — Jesus! Não! Não! — Os seus olhos cerraram-se. (I, p. 570)

Aqui, na entrega, o contraste se acentua. Leopoldina pede o bacalhau e o alho; mantém marido e amantes; seduz tanto quanto se deixa seduzir. Luísa não revela essa mesma agilidade e força. Frágil na mesa, frágil no amor: deixa-se seduzir e entrega-se ao amante, dentro da própria casa, quase diante das criadas, comprometendo definitivamente a "respeitabilidade do lar".

Retomando a analogia entre cozinha e literatura que procurei estabelecer no início deste artigo: das possíveis "receitas" para as mulheres de uma família da burguesia lisboeta, Eça de Queirós parece ter seguido a mesma para “cozer” Luísa e Leopoldina: são vizinhas, 
estudam num mesmo colégio, partilham experiências amorosas, encomendam roupas nas mesmas modistas, comem às mesmas mesas, casam-se e, se desejam amantes, precisam lidar com as exigências e desmazelos das criadas. As diferenças aparecem na maneira como modelam essas experiências e na importância que dão a certos aspectos da vida, ou seja, no "tempero" e no "modo de preparo". E o bacalhau com alho simboliza esse contraste. Extravagância para Luísa, prazer para Leopoldina. O extravagante prato é um símbolo do destemor de Leopoldina para questionar padrões de convivência, gastronômica e amorosa, sem deixar de aceitá-los quando é conveniente. Coragem que Luísa não desenvolve: entregase ao amante em sua própria casa, mas terá dificuldade para saborear e, depois, divertir-se com a aventura. Quem conhece o romance sabe que Luísa não conseguirá comer "bacalhau com alho", nem flexibilizar suas concepções e "lidar com as criadas quando se precisa delas".

A caracterização de Luísa e Leopoldina à mesa é coerente com os seus destinos na narrativa. E a análise desse episódio gastronômico d'O Primo Basílio é um exemplo de que comida e comer não são acessórios no texto eciano. No projeto de representação da sociedade portuguesa, cardápio, maneiras e companhias à mesa constituem a base do alicerce social e concretizam o programa que Eça de Queirós expôs no texto "Cozinha Arqueológica”: "diga-me o que [como e com quem] comes e dir-te-ei quem és".

\section{Referências Bibliográficas}

ALLENDE, Isabel. Afrodite: contos, receitas e outros afrodisiacos; ilustrações Robert Shekter; receitas Panchita Llona; tradução Claudia Schilling. Rio de Janeiro: Bertrand, 1998.

ALVES, Dario Moreira de Castro. Era Tormes e Amanhecia: dicionário gastronômico cultural de Eça de Queirós. Rio de Janeiro: Nordica, 1992.

ANDRADE, José Roberto de. Comer e comer: um verbo, dois (re)cortes em O Crime do Padre Amaro. Revista Eletrônica do IFBA. Ano 3, No 3, Julho-Dezembro/2012, p. 33-45. Disponível em < http://www.revistapindorama.ifba.edu.br/ed_atual.php>. Acesso em 16 jan. 2013.

ANDRADE, José Roberto de. Culinária e modificações do gosto em Eça de Queirós: O Crime do Padre Amaro e Os Maias. In: Petrov, Petar; Sousa, Pedro Quintino de; Samartim, Roberto López-Iglésias \& Torres Feijó, Elias J. (eds.). Avanços em Literatura e Cultura Portuguesas. De Eça de Queirós a Fernando Pessoa. Santiago de Compostela-Faro: Associação Internacional de Lusitanistas-Através Editora, 2012, p. 141-158. Depósito legal: C 594-2012 ANDRADE, José Roberto de. Intermitência gastronômica? Sonho, realidade e farsa n'A Relíquia e n'O Mandarim. Anais do XXIII Congresso Internacional da Associação Brasileira de Professores de Literatura Portuguesa (ABRAPLIP). Disponível em: <http://www.abraplip. org/anais_abraplip/images/stories/Jose $\% 20$ Roberto $\% 20 \mathrm{de} \% 20$ Andrade.pdf $>$. Acesso em 12 dez. 2012. 
ASSIS, Machado. Eça de Queirós: O Primo Basílio. In: Obra Completa. V. III. Rio de Janeiro: Aguillar, 1997, p. 903-913.

BERRINI, Beatriz (Org.). Comer e beber com Eça de Queirós. Rio de Janeiro: Index, 1995.

BERRINI, Beatriz. Eça de Queirós e os prazeres da mesa. Semear, Rio de Janeiro, v. 01, n. 01, p. 53-66, 1997.

CAL, Ernesto Guerra da. Lingua e Estilo de Eça de Queirós. São Paulo: Edusp; Rio de Janeiro: Ed. Tempo Brasileiro, 1969.

FLANDRIN, Jean-Louis. A distinção pelo Gosto. In: Aries, Fhiplipe e Chartier, Roger. História da Vida Privada 3: da Renascença ao Século das Luz̧es. Tradução Hildegard Feist. São Paulo: Companhia das Letras, 1991. P. 267-309.

KELLY, Ian. Carême: cożinheiro dos reis. Rio de Janeiro: Jorge Zahar Editor, 2005.

LIMA, Isabel Pires de. "Fulgurações e Ofuscações de Eros - O Primo Basílio". In: Anais do III Encontro Internacional de Queirosianos: 150 anos com Eça de Queirós, realizado em São Paulo, 1995. São Paulo: Centro de Estudos Portugueses: Área de Estudos Comparados de Literatura de Língua Portuguesa/FFLCH/USP, 1997, p. 715-721.

MATOS, Alfredo de Campos (Org.). Dicionário de Eça de Queiroz. 2. ed. Lisboa: Caminho, 1988.

MÓNICA, Maria Filomena. Eça de Queirós. Lisboa: Quetzal Editores, 2001.

MONTANARI, Massimo. La Comida como cultura. Espanha: Ediciones Trea, 2004

NERY, Antonio Augusto. Eça de Queirós versus Papa Leão XIII: questões alimentares. Horizonte, Belo Horizonte, v. 10, n. 28, p. 1363-1379, out./dez. 2012.

QUEIRÓS, Eça de. Obra Completa: quatro volumes. Organização geral, introdução, fixação dos textos autógrafos e notas introdutórias Beatriz Berrini. Rio de Janeiro: Aguilar, 1997.

QUEIROZ, Maria José de. A Literatura e o gozo impuro da comida. Rio de Janeiro: Topbooks, 1994.

QUITÉRIO, José. Histórias e curiosidades gastronômicas. Lisboa: Assírio \& Alvim, 2005

QUITÉRIO, José. Livro do bem comer: crônicas de gastronomia portuguesa. Lisboa: Assírio \& Alvim, 1987.

LIMA, Isabel Pires de. Fulgurações e Ofuscações de Eros - O Primo Basilio - In: Anais do III Encontro Internacional de Queirosianos: 150 anos com Eça de Queirós, realizado em São Paulo, 1995. São Paulo: Centro de Estudos Portugueses: Área de Estudos Comparados de Literatura de Língua Portuguesa/FFLCH/USP, 1997, p. 715-721.

REIS, Carlos. O essencial sobre Eça de Queirós. Lisboa: Ed. Imprensa Nacional, 2000.

REVEL, Jean-François. Um banquete de palavras: uma história da sensibilidade gastronômica; tradução Paulo Neves. São Paulo: Companhia das Letras, 1996.

SAVARIN, Brillart. A fisiologia do gosto. Tradução Paulo Neves. São Paulo: Companhia das Letras, 1995.

STRONG, Roy C. Banquete: uma história ilustrada da culinária e dos costumes e da fartura à mesa. Rio de Janeiro: Jorge Zahar Ed., 2004.

THERBORN, Göran. Sexo e Poder: A família no mundo 1900-2000. São Paulo: Contexto, 2006. WERNEK, Francisco José dos Santos. As ideias de Eça de Queirós. Rio De Janeiro: Livraria AGIR Editora, 1946. 